\title{
The effect of biofertilizer and inorganic fertilizer on the vegetative growth of sugarcane (Saccharum Officinarum)
}

\author{
Sudiarso ${ }^{1^{*}}$, Ririen Prihandarini ${ }^{2}$ \\ ${ }^{1}$ Faculty of Agriculture, University of Brawijaya, Malang, Indonesia \\ ${ }^{2}$ Faculty of Agriculture, University Widya Gama, Malang, Indonesia
}

\author{
Keywords \\ Biological agents \\ Inorganic fertilizer \\ Sugar \\ Combination
}

Received: 3 December 2017

Accepted: 9 January 2018

Published: 7 February 2018

\begin{abstract}
The purpose of this rearch is to know the effect of the combination of biological agents with inorganic fertilizers and finding the correct dose for the combination of biological agents with inorganic fertilizer for the growth of sugarcane. The research was conducted in the village Pakiskembar, Pakis, subdistrict Malang. The study used a randomized block design with 7 treatments and 4 replications. Data were analyzed using Analysis of Variance (ANOVA); if there is a significant difference, then it is followed by a further test of LSD 5\%. The results showed the effect of the combination of inorganic fertilizer with biological agents. There are significant differences in plant height and length of the rod at 139 DAP, stem diameter at 153 DAP, and the number of tillers at 97 DAP. P5 (NPK $300 \mathrm{~kg} \mathrm{ha}^{-1}+\mathrm{ZA} 400 \mathrm{~kg} \mathrm{ha}^{-1}+$ Biofertilizer $30 \mathrm{~L} \mathrm{ha}^{-1}$ ) is known to give good growth in most but not significantly different from P1 (NPK $400 \mathrm{~kg} \mathrm{ha}^{-1}+\mathrm{ZA} 600 \mathrm{~kg} \mathrm{ha}^{-1}$ ). A combination of inorganic fertilizer with biological agents can lower the dose of inorganic fertilizer, and biological agents can provide nutrients needed for sugarcane so that the use of inorganic fertilizers can be reduced.
\end{abstract}

(C) 2018 The Author(s). Published by TAF Publishing.

\section{INTRODUCTION}

The sugarcane plant (Saccharum officinarum) is a plantation cultivated in Indonesia in an effort to supply sugar as a staple needed for industry and daily consumption. Based on data from the Central Bureau of Statistics (BPS), national sugar production in 2014 is about 2,575.40 tonnes produced from an area of 209,800 ha. With the increase of sugar demand every year, sugarcane production is required to be improved. Some efforts that can be made to increase sugarcane production are through the provision of quality planting materials, good environmental conditions, nutrient adequacy, and other environmental factors.

Sugarcane is an annual crop that requires enormous amounts of nutrients during its growth [1, 2, 3]. During its growth, the cane absorbs between $50-500 \mathrm{~kg} \mathrm{~N} \mathrm{ha}^{-1}, 40-80$ kg $\mathrm{P} \mathrm{ha}^{-1}$, and $100-300 \mathrm{~kg} \mathrm{~K} \mathrm{ha}^{-1}$ [4]. It shows that sugarcane plants need nutrients $\mathrm{N}, \mathrm{P}$, and $\mathrm{K}$ in very large quantities. Therefore, in fulfillment of this nutrient needs, fertilizer efficiency is needed so that the fertilizer is given no shortage or excess.

Fertilization using inorganic fertilizers can show faster and better results when compared to the use of organic fertilizers, but when considering the impact on environmental conditions, inorganic fertilization can adversely affect the environment, especially soil conditions. A solution is needed to create an environmentally friendly farm by reducing dependence on chemicals. Therefore, the application of biological fertilizer combined with inorganic fertilizer is expected to reduce the adverse effects of inorganic fertilizer use. Given the combination of bio-fertilizer and inorganic fertilizer, it is expected that the growth of sugarcane remains optimal but can protect the soil from excessive chemicals. Biological fertilizers differ from artificial chemical fertilizers, such as urea, TSP, and others, because in biological fertilizers, the main components are living organisms that are generally obtained from nature without any addition of chemicals except chemicals needed to support the growth of their living bodies during storage $[5,6,7]$.

\footnotetext{
${ }^{*}$ Corresponding author: Sudiarso

†email: sudiarso_fpub@yahoo.co.id
} 
Biological fertilizers have been reported to improve nutrient uptake efficiency, improve growth and yield, and increase resistance to pests and diseases. Biological fertilizers play a role in influencing the availability of macro and micro nutrients, nutrient efficiency, performance of enzyme systems, and increasing growth metabolism and crop yield. This technology has a more promising prospect as well as its real impact on improving yield, also more environmentally friendly $[8,9,10]$.

The purpose of this study was to study biological agents that can inhibit $\mathrm{N}_{2}$ and dissolve $\mathrm{P}$ in the soil, to know the effect of biological agents and inorganic fertilizers on vegetative growth of sugarcane and to obtain the proper dosage from the combination of inorganic fertilizers and biological agents for optimal vegetative growth of sugarcane.

\section{MATERIAL AND METHODS}

This research was conducted in Pakiskembar village, Pakis District of Malang Regency, East Java which is located at an altitude of $\pm 450 \mathrm{mdpl}$. This study was conducted from October 2015 to April 2016. The tools used in this study include hoes, knapsack sprayer, bucket, measuring cylinder, sliding wheel, calculator, camera, meter, nameplate, and stationery. The materials used are varieties of sugarcane varieties Bululawang (BL) keprasan-3, fertilizer NPK 15-15-15 (Phonska), ZA fertilizer, biological fertilizer P11, water, and compost.

The study was conducted using Group Random Design (RAK) with 7 treatments and 4 replications.

P0: control

P1: NPK $400 \mathrm{~kg} \mathrm{ha}^{-1}+\mathrm{ZA} 600 \mathrm{~kg} \mathrm{ha}^{-1}$

P2: PH $30 \mathrm{~L} \mathrm{ha}^{-1}$

P3: NPK $100 \mathrm{~kg} \mathrm{ha}^{-1}+\mathrm{ZA} 150 \mathrm{~kg} \mathrm{ha}^{-1}+\mathrm{PH} 30 \mathrm{~L} \mathrm{ha}^{-1}$

P4: NPK $200 \mathrm{~kg} \mathrm{ha}^{-1}+\mathrm{ZA} 300 \mathrm{~kg} \mathrm{ha}^{-1}+\mathrm{PH} 30 \mathrm{~L} \mathrm{ha}^{-1}$

P5: NPK $300 \mathrm{~kg} \mathrm{ha}^{-1}+\mathrm{ZA} 400 \mathrm{~kg} \mathrm{ha}^{-1}+\mathrm{PH} 30 \mathrm{~L} \mathrm{ha}^{-1}$

P6: NPK $200 \mathrm{~kg} \mathrm{ha}^{-1}+\mathrm{ZA} 300 \mathrm{~kg} \mathrm{ha}^{-1}+$ PH $15 \mathrm{~L} \mathrm{ha}^{-1}$

Observations made are observations of vegetative cane organs including: 1 . Plant height, measured from the ground to the point of growing; 2 . The length of the stem, measured from the surface of the soil to the top of the cane stem; 3 . The diameter of the stem, measured using a sliding term; 4 . Number of tillers, calculating the number of population in each sample plot. All data obtained were analyzed by F-test with $5 \%$ level. If the results show a real effect, then proceed

with BNT test at 5\% level to know the difference from each treatment.

\section{A. General Research Results}

Thse: resultss showed that there were significant differences

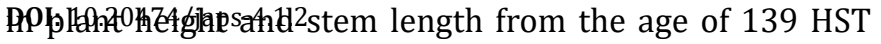

\section{RESULTS AND DISCUSSION}

(Tables 1 and 2). The number of tillers was known to differ significantly since the age of 97 HST (Table 3), (Table 4). From the results, it can be seen that the uptake of nutrients received by plants is more clearly visible on the growth of sugarcane stems from the age of 139 HST while the number of seedlings is known to require sufficient nutrients in the phase of germination and perunation to look for the difference at the age of 97 HST.

Growth of sugarcane plants can be seen clearly in the increase in the volume of stems where there is a high increase, the formation of the segment, the formation of young leaves at the top, and the increase in diameter of the stem. Based on the results of the research, it can be seen that the dose of fertilizer that has the best effect on the growth of sugarcane plant is P5 (NPK $300 \mathrm{~kg} \mathrm{ha}^{-1}+\mathrm{ZA} 400 \mathrm{~kg} \mathrm{ha}^{-1}+\mathrm{Bi}-$ Fertilizer $30 \mathrm{~L} \mathrm{ha}^{-1}$ ). In P5, it can be seen that the overall observation parameters experienced the best growth when compared with other treatments. This shows that the dose is more effective when compared with other doses and also nutrient uptake is good enough so that the vegetative organs grow well.

The main organ of sugarcane is the stem. Cane stems can grow up to 4-5 $\mathrm{m}$. The outer layer of sugarcane stems has a hard surface whereas it is composed of a network in which the stored part of the sugar content of sucrose is present. The most active process of sugarcane growth occurs in the elongation phase during the age of 3-9 months after planting. This requires the nutrient sufficiency because in this phase, active sugarcane plants absorb nutrients for growth. Stem growth is an important phase for sugarcane because it determines the amount of weight produced [11].

\section{B. Plant Height}

The indicator of sugarcane growing optimally can be considered through its growth. P5 is known to show the best result with a height of $277.60 \mathrm{~cm}$ at the end of the observation and significantly different from the overall treatment (Table 1).

The vegetative phase of sugarcane plants actively absorbs nutrients, especially during the elongation phase. The results showed that treatment of P5 (NPK $300 \mathrm{~kg} \mathrm{ha}^{-1}+$ ZA

$400 \mathrm{~kg} \mathrm{ha}^{-1}+$ Biomass Fertilizer $30 \mathrm{~L} \mathrm{ha}^{-1}$ ) significantly increased the height of sugarcane plant. The nutrient element that plays a role in adding sugarcane is nitrogen. [12] stated that $\mathrm{N}$ element is very important for growth and yield of sugarcane. The main role of nitrogen for sugarcane is to spur overall growth, especially stems, tillers, and leaves. 
TABLE 1

MEAN OF PLANT HEIGHT

\begin{tabular}{lccccccc}
\hline \hline Treatment & \multicolumn{7}{c}{ Average Height of Cane Plant (cm) HST-1 } \\
\cline { 2 - 8 } & 97 & 111 & 125 & 139 & 153 & 167 & 181 \\
\hline $\mathrm{P}_{0}$ & 95.90 & 118.10 & 133.73 & $154.43 \mathrm{a}$ & $178.00 \mathrm{a}$ & $213.83 \mathrm{a}$ & $224.45 \mathrm{a}$ \\
$\mathrm{P}_{1}$ & 110.48 & 128.20 & 155.43 & $179.03 \mathrm{~cd}$ & $207.78 \mathrm{de}$ & $237.70 \mathrm{~cd}$ & $256.45 \mathrm{c}$ \\
$\mathrm{P}_{2}$ & 99.40 & 120.78 & 141.85 & $155.05 \mathrm{ab}$ & $187.60 \mathrm{ab}$ & $217.48 \mathrm{ab}$ & $229.00 \mathrm{a}$ \\
$\mathrm{P}_{3}$ & 99.60 & 124.83 & 150.78 & $167.50 \mathrm{abc}$ & $188.25 \mathrm{abc}$ & $221.85 \mathrm{abc}$ & $240.15 \mathrm{ab}$ \\
$\mathrm{P}_{4}$ & 105.68 & 124.50 & 151.33 & $169.40 \mathrm{bcd}$ & $196.50 \mathrm{bcd}$ & $233.68 \mathrm{bc}$ & $253.30 \mathrm{bc}$ \\
$\mathrm{P}_{5}$ & 117.48 & 132.75 & 154.48 & $181.98 \mathrm{~d}$ & $218.93 \mathrm{e}$ & $254.35 \mathrm{~d}$ & $277.60 \mathrm{~d}$ \\
$\mathrm{P}_{6}$ & 105.33 & 123.13 & 140.65 & $169.15 \mathrm{bcd}$ & $203.30 \mathrm{~cd}$ & $226.25 \mathrm{abc}$ & $248.38 \mathrm{bc}$ \\
\hline \hline
\end{tabular}

Description: Numbers accompanied by the same letter in the same column show no significant difference in 5\% BNT test.

\section{Rod Length}

Sugarcane plants that grow high will form the segments on the trunk. The formation of this segment indicates that the sugarcane starts to undergo stem lengthening. [12] suggest that bar length represents a growth process in meristematic, tip or apical areas. The increase in sugarcane height is directly proportional to the fresh weight of biomass. The length of the stem and the number of sections indicate that growth of cane plant runs optimally. P5 (NPK $300 \mathrm{~kg} \mathrm{ha}^{-1}+$ ZA $400 \mathrm{~kg} \mathrm{ha}^{-1}+$ Biomass Fertilizer $30 \mathrm{~L} \mathrm{ha}^{-1}$ ) significantly increased stem length, number of segments, and length of segment (Table 2).

TABLE 2

AVERAGE LENGTH OF STEMS

\begin{tabular}{lccccccc}
\hline \hline Treatment & \multicolumn{7}{c}{ Average Sugar Cane Length (cm) HST-1 } \\
\cline { 2 - 7 } & 97 & 111 & 125 & 139 & 153 & 167 & 181 \\
\hline $\mathrm{P}_{0}$ & 19.33 & 44.00 & 76.03 & $103.30 \mathrm{a}$ & $130.95 \mathrm{a}$ & $155.95 \mathrm{a}$ & $179.18 \mathrm{a}$ \\
$\mathrm{P}_{1}$ & 21.53 & 50.08 & 82.60 & $130.13 \mathrm{~d}$ & $163.13 \mathrm{c}$ & $197.20 \mathrm{c}$ & $230.95 \mathrm{c}$ \\
$\mathrm{P}_{2}$ & 19.88 & 44.35 & 76.30 & $110.03 \mathrm{ab}$ & $136.23 \mathrm{ab}$ & $162.73 \mathrm{ab}$ & $191.98 \mathrm{ab}$ \\
$\mathrm{P}_{3}$ & 20.00 & 47.38 & 78.78 & $118.88 \mathrm{bc}$ & $140.60 \mathrm{ab}$ & $168.60 \mathrm{ab}$ & $201.48 \mathrm{~b}$ \\
$\mathrm{P}_{4}$ & 20.65 & 47.73 & 79.45 & $125.48 \mathrm{~cd}$ & $159.23 \mathrm{c}$ & $192.48 \mathrm{c}$ & $226.55 \mathrm{c}$ \\
$\mathrm{P}_{5}$ & 22.30 & 51.55 & 86.55 & $134.78 \mathrm{~d}$ & $177.53 \mathrm{~d}$ & $214.38 \mathrm{~d}$ & $247.58 \mathrm{~d}$ \\
$\mathrm{P}_{6}$ & 20.53 & 47.20 & 78.83 & $123.98 \mathrm{~cd}$ & $144.98 \mathrm{~b}$ & $173.48 \mathrm{~b}$ & $206.03 \mathrm{~b}$ \\
BNT 5\% & tn & tn & tn & 11.02 & 13.76 & 14.54 & 16.27 \\
\hline \hline
\end{tabular}

Description: Numbers accompanied by the same letter in the same column show no significant difference in 5\% BNT test.

The real difference starts to appear when entering the age of 139 HST. At the age of 139 HST, the highest stem length was shown by the treatment of P5 (NPK $300 \mathrm{~kg} \mathrm{ha}^{-1}+$ ZA $400 \mathrm{~kg}$ $\mathrm{ha}^{-1}+30 \mathrm{~L} \mathrm{ha}^{-1}$ ), i.e., $134.78 \mathrm{~cm}$ but not significantly different from P1 (NPK $400 \mathrm{~kg} \mathrm{ha}^{-1}+\mathrm{ZA} 600 \mathrm{~kg} \mathrm{ha}^{-1}$ ) $130.13 \mathrm{~cm}$, P4 (NPK $200 \mathrm{~kg} \mathrm{ha}^{-1}+$ ZA $300 \mathrm{~kg} \mathrm{ha}^{-1}+$ Biomass Fertilizer $30 \mathrm{~L} \mathrm{ha}^{-1}$ ) $125.48 \mathrm{~cm}$, and P6 (NPK $200 \mathrm{~kg} \mathrm{ha}^{-1}+\mathrm{ZA} 300$ $\mathrm{kg} \mathrm{ha}^{-1}+15 \mathrm{~L} \mathrm{ha}^{-1}$ ) $123.98 \mathrm{~cm}$. At the age of $153 \mathrm{HST}, 167$ HST, and 181 HST known, P5 treatment showed the highest stem length compared to other treatments with a length of $247.58 \mathrm{~cm}$ at the end of the observation. It also indicates that on the stem of sugarcane, the process of accumulation of the result of photosynthesis asmiliasi. Similarly, for plant height, the formation of this segment is strongly influenced by the uptake of nutrients by the roots.

[13] say that vegetable propagated cane requires substantial nutrients for the growth of organs, especially elements of $\mathrm{N}$ and $\mathrm{K}$. Element $\mathrm{K}$ is absorbed by sugarcane in the form of $\mathrm{K}+$. The $\mathrm{K}$ element serves as an enzyme activator in plant metabolism, such as photosynthesis, protein synthesis, starch formation, and protein and sugar translocation [14]. In addition to $\mathrm{N}$ and $\mathrm{K}$, sugarcane also absorbs phosphorus which serves as a structural component of a number of energy transferring molecular compounds. Phosphorus is needed for the formation of cells in the growing tissues, including stems and roots [15].

Growth of sugarcane stalk is the most important phase in sugarcane cultivation. The length of sugarcane stems illus- 
trates the accumulation of sucrose sugar produced so that the longer the stem of sugarcane, the more sugar heaps will be produced. This stem growth occurs as a result of shoot growth in sugarcane and growth on the basis of the segment [11]. The more the number of segments, the more the stem length increases.

\section{Stem Diameter}

The diameter of the stem is one of the parameters that can be measured to assess the growth of sugarcane. The magnitude of the diameter illustrates the increase in the weight of sugar or sucrose in the cane. The results showed that treatment of P5 (NPK $300 \mathrm{~kg} \mathrm{ha}^{-1}+\mathrm{ZA} 400 \mathrm{~kg} \mathrm{ha}^{-1}+$ Biomass Fertilizer $30 \mathrm{~L} \mathrm{ha}^{-1}$ ) significantly increased stem diameter (Table 3). The real difference came into sight when the sugarcane was 153 HST.

TABLE 3

AVERAGE STEM DIAMETER

\begin{tabular}{lccccccc}
\hline \hline Treatment & \multicolumn{7}{c}{ Average Sugar Cane Diameter (mm) HST-1 } \\
\cline { 2 - 8 } & 97 & 111 & 125 & 139 & 153 & 167 & 181 \\
\hline $\mathrm{P}_{0}$ & 24.16 & 24.84 & 24.84 & 26.00 & $26.47 \mathrm{a}$ & $27.20 \mathrm{a}$ & $27.52 \mathrm{a}$ \\
$\mathrm{P}_{1}$ & 25.44 & 25.95 & 26.67 & 27.78 & $28.57 \mathrm{~cd}$ & $29.15 \mathrm{bc}$ & $30.10 \mathrm{~cd}$ \\
$\mathrm{P}_{2}$ & 24.47 & 24.96 & 25.71 & 26.27 & $26.82 \mathrm{ab}$ & $27.27 \mathrm{a}$ & $27.61 \mathrm{a}$ \\
$\mathrm{P}_{3}$ & 24.89 & 25.37 & 25.95 & 26.49 & $27.20 \mathrm{abc}$ & $27.90 \mathrm{ab}$ & $28.45 \mathrm{ab}$ \\
$\mathrm{P}_{4}$ & 25.25 & 25.88 & 26.68 & 27.36 & $28.06 \mathrm{bcd}$ & $28.60 \mathrm{abc}$ & $29.12 \mathrm{bc}$ \\
$\mathrm{P}_{5}$ & 25.55 & 26.20 & 27.11 & 28.49 & $29.39 \mathrm{~d}$ & $29.94 \mathrm{c}$ & $30.85 \mathrm{~d}$ \\
$\mathrm{P}_{6}$ & 25.96 & 25.74 & 26.60 & 26.95 & $27.53 \mathrm{abc}$ & $28.12 \mathrm{ab}$ & $28.60 \mathrm{ab}$ \\
BNT 5\% & tn & th & tn & th & 1.51 & 1.50 & 1.37 \\
\hline \hline
\end{tabular}

Description: Numbers accompanied by the same letter in the same column show no significant difference in $5 \%$ BNT test.

From Table 3, it can be seen at the age of 153 HST and 167 HST, P5 (NPK $300 \mathrm{~kg} \mathrm{ha}^{-1}+\mathrm{ZA} 400 \mathrm{~kg} \mathrm{ha}^{-1}+30 \mathrm{~L} \mathrm{ha}^{-1}$ ) is not significantly different from P1 (NPK $400 \mathrm{~kg} \mathrm{ha}^{-1}+\mathrm{ZA}$ $600 \mathrm{~kg} \mathrm{ha}^{-1}$ ) and P4 (NPK $200 \mathrm{~kg} \mathrm{ha}^{-1}+\mathrm{ZA} 300 \mathrm{~kg} \mathrm{ha}^{-1}+$ Bi-Fertilizer $30 \mathrm{~L} \mathrm{ha}^{-1}$ ) while at $181 \mathrm{HST}$, P5 (NPK $300 \mathrm{~kg}$ $\mathrm{ha}^{-1}+$ ZA $400 \mathrm{~kg} \mathrm{ha}^{-1}+$ Biomass Fertilizer $30 \mathrm{~L} \mathrm{ha}^{-1}$ ) has a diameter of $30.85 \mathrm{~mm}$ known not significantly different from P1 (NPK $400 \mathrm{~kg} \mathrm{ha}^{-1}+$ ZA $600 \mathrm{~kg} \mathrm{ha}^{-1}$ ) which has a diameter of $30.10 \mathrm{~mm}$.

Magnification of stem diameter occurs due to enlargement of existing tissues in the stem. Nutrients have an important role in each volume increase in plant organs. Lack of nutrients $\mathrm{N}, \mathrm{P}$, and $\mathrm{K}$ will inhibit plant growth because these elements support the process of photosynthesis. Lack of nutrients can lead to a decrease in photosynthetic rate that can cause shorter stems, shorter stems, and also small diameter $[14,16]$. The results of photosynthesis will largely be stored on the stem of the sugarcane plant in the form of sucrose and most will be used for the vegetative growth process [12].

\section{E. Number of Tillers}

The treatment of P1 (NPK $400 \mathrm{~kg} \mathrm{ha}^{-1}+$ ZA $600 \mathrm{~kg} \mathrm{ha}^{-1}$ ) was known to have a significant effect on the growth of the seedlings but not significantly different from the treatment of P5 (NPK $300 \mathrm{~kg} \mathrm{ha}^{-1}+$ ZA $400 \mathrm{~kg} \mathrm{ha}^{-1}+^{-1}$ ) (Table 4). This happens because the application of NPK fertilizer is done 2 weeks after keprasan and the time is the time when new buds start to appear and need enough nutrients to support its growth. Nitrogen is the most dominant element among the elements needed by sugarcane, which functions among others to encourage the formation of saplings which will eventually increase the number of stems and weight of stems per hectare so that it will increase production [12]. In the growth phase, the saplings will have the potential to produce the optimal weight of sugarcane. The number of tillers on sugarcane is very influential on the production produced so that with the increasing number of tillers will be the higher the production to be produced [11]. The vegetative phase of sugarcane plant consists of germination, 
replanting, and lengthening. The existing population in a sugarcane is determined by germination and replanting process because that phase can be known from how many buds of sugarcane will grow. Sugarcane buds that have experienced the pertunasan are referred to as saplings. Phase of replanting is the process of the release of new seedling shoots that come out from the base of young sugarcane (primary shoots). This process lasts from sugarcane age 5 weeks to 3-4 months (depending on variety). Natural resources required in this phase include: water, sunlight, $\mathrm{N}$ and $\mathrm{P}$, and oxygen for respiration and root growth [17].

TABLE 4

AVERAGE NUMBER OF TILLERS

\begin{tabular}{lccccccc}
\hline Treatment & \multicolumn{7}{c}{ Average Number of Sugar Cane (Stems) HST-1 } \\
\cline { 2 - 7 } & 97 & 111 & 125 & 139 & 153 & 167 & 181 \\
\hline P0 & $12.58 \mathrm{a}$ & $13.13 \mathrm{a}$ & $13.80 \mathrm{a}$ & $14.15 \mathrm{a}$ & $14.21 \mathrm{a}$ & $14.33 \mathrm{a}$ & $14.38 \mathrm{a}$ \\
P1 & $18.15 \mathrm{~d}$ & $18.93 \mathrm{~d}$ & $19.35 \mathrm{~d}$ & $19.55 \mathrm{~d}$ & $19.63 \mathrm{~d}$ & $19.68 \mathrm{~d}$ & $19.75 \mathrm{~d}$ \\
P2 & $13.65 \mathrm{ab}$ & $14.43 \mathrm{ab}$ & $15.05 \mathrm{ab}$ & $15.10 \mathrm{ab}$ & $15.18 \mathrm{ab}$ & $15.20 \mathrm{ab}$ & $15.30 \mathrm{ab}$ \\
P3 & $14.75 \mathrm{abc}$ & $15.70 \mathrm{abc}$ & $16.78 \mathrm{bcd}$ & $16.90 \mathrm{bcd}$ & $16.98 \mathrm{bc}$ & $16.98 \mathrm{bc}$ & $16.98 \mathrm{bc}$ \\
P4 & $15.88 \mathrm{bcd}$ & $16.38 \mathrm{bcd}$ & $16.50 \mathrm{abc}$ & $17.00 \mathrm{bcd}$ & $17.00 \mathrm{bc}$ & $17.05 \mathrm{bc}$ & $17.15 \mathrm{bc}$ \\
P5 & $17.08 \mathrm{~cd}$ & $18.00 \mathrm{~cd}$ & $18.28 \mathrm{~cd}$ & $18.28 \mathrm{~cd}$ & $18.33 \mathrm{~cd}$ & $18.35 \mathrm{~cd}$ & $18.58 \mathrm{~cd}$ \\
P6 & $15.66 \mathrm{bcd}$ & $16.13 \mathrm{abcd}$ & $16.58 \mathrm{abcd}$ & $16.58 \mathrm{abc}$ & $16.73 \mathrm{abc}$ & $16.75 \mathrm{abc}$ & $16.78 \mathrm{abc}$ \\
BNT 5\% & 2.91 & 3.01 & 2.83 & 2.66 & 2.59 & 2.54 & 2.49 \\
\hline \hline
\end{tabular}

Description: Numbers accompanied by the same letter in the same column show no significant difference in $5 \%$ BNT test.

This research utilized sugarcane keprasan. The results of sugarcane keprasan known decreased by $20 \%$ of the first plant (Plant cane). This occurs due to the decline in the population of saplings or sugarcane stems caused by the death of buds or shoots. Deaths of shoots or tillers occur due to competition of environmental factors, such as sunlight, space to grow, and also the nutrients needed. It is also influenced by the varieties of sugarcane used. Not all cane varieties can tolerate the polishing [18]. Therefore, in order to obtain good results during harvest, it is necessary to maintain good for shoots that have grown into sugarcane in order to avoid enlargement of productivity decline.

\section{CONCLUSION}

Based on the data obtained from this study, it can be concluded that the treatment of P5 (NPK $300 \mathrm{~kg} \mathrm{ha}^{-1}+$ ZA 400 $\mathrm{kg} \mathrm{ha} \mathrm{a}^{-1}+\mathrm{PH} 30 \mathrm{~L} \mathrm{ha}^{-1}$ ) is not significantly different from treatment of P1 (NPK $400 \mathrm{~kg} \mathrm{ha}^{-1}+$ ZA $600 \mathrm{~kg} \mathrm{ha}^{-1}$ ) and provides the best effect for vegetative growth of sugarcane compared to other treatments. Based on the research results, it can be seen that P5 (NPK $300 \mathrm{~kg} \mathrm{ha}^{-1}+$ ZA $400 \mathrm{~kg}$ $\mathrm{ha}^{-1}+\mathrm{PH} 30 \mathrm{~L} \mathrm{ha}^{-1}$ ) can decrease the dose of chemical fertilizer, and application of biofertilizer containing $\mathrm{N}$ and $\mathrm{N}$ soluble bacteria can provide $\mathrm{N}$ and $\mathrm{P}$ nutrient requirements in the vegetative phase of sugarcane so as to decrease the dose of inorganic fertilizers.

\section{REFERENCES}

[1] A. K. V. Chernenok, A. Kurishbayev and Y. Nurmanov, 'Diagnostics and optimization of crops' nitrogen nutrition in rainfed conditions of the northern kazakhstan," Journal of Applied and Physical Sciences, vol. 1, no. 1, pp. 1-8, 2015. doi: 10.20474/-japs1.1.1

[2] M. Chohan, R. Pahnwar, B. Qazi, S. Junejo, G. Unar, M. Arain, U. Talpur et al., “Quantitative and qualitative parameters of sugarcane variety hoth-300 as affected by different levels of npk applications," Journal of Animal \& Plant Sciences, vol. 22, no. 4, pp. 1060-1064, 2012.

[3] H. T. T. Hanh and W. Mongkolthanaruk, "Correlation of growth and IAA production of lysinibacillus fusiformis ud 270," Journal of Applied and Physical Sciences, vol. 3, no. 3, pp. 98-106, 2017. doi: 10.20474/japs-3.3.3

[4] E. Yukamgo and N. W. Yuwono, "Peran silikon sebagai unsur bermanfaat pada tanaman tebu," Jurnal Ilmu Tanah dan Lingkungan, vol. 7, no. 2, pp. 103-116, 2007.

[5] D. Abdurahman, Biologi Kelompok Pertanian. Bandung, Indoneisa: PT Grafindo Media Pratama, 2008. 
[6] R. A. H. Hutagalung, S. Magdalena, I. Iskandar, and S. Mastrorillo, "Increasing growth and survival rate of land hermit crabs (coenobita sp.) in artificial habitat through feeding habit," International Journal of Applied and Physical Sciences, vol. 3, no. 3, pp. 55-59, 2017. doi: 10.20469/ijaps.3.50001-3

[7] A. A. B. M. Azoddein, R. B. M. Yunus, N. M. B. N. Sulaiman, A. B. B. Bustary, F. A. B. M. Azli, and S. B. C. Sayuti, “Effect of mercury concentration on p. putida growth in mercury removal," Journal of Applied and Physical Sciences, vol. 3, no. 3, pp. 107-116, 2017. doi: 10.20474/japs-3.3.4

[8] T. Agung and A. Y. Rahayu, “Analisis efisiensi serapan n, pertumbuhan, dan hasil beberapa kultivar kedelai unggul baru dengan cekaman kekeringan dan pemberian pupuk hayati," Agrosains, vol. 6, no. 2, pp. 70-74, 2004.

[9] S. Nadyrov, G. Geldyena, G. Nussupova, and A. Skakova, “Geographical aspects of organizing natural resource management structure in kazakhstani section of a new economic zone of the silk road," International Journal of Applied and Physical Sciences, vol. 2, no. 3, pp. 59-64, 2016. doi: 10.20469/ijaps.2.50001-3

[10] P. Roya, R. Hadi, A. Hossein, and M. Vahedian, "Survey of wastewater stabilization pond potential in meeting environmental standards," International Journal of Applied and Physical Sciences, vol. 1, no. 1, pp. 19-21, 2015. doi: 10.20469/ijaps.50003

[11] R. A. Harjanti, S. N. H. U. Tohari et al., "Pengaruh takaran pupuk nitrogen dan silika terhadap pertumbuhan awal (Saccharum officinarum L.) pada inceptisol," Vegetalika, vol. 3, no. 2, pp. 35-44, 2014.

[12] N. L. Nikmah et al., "Respon pertumbuhan vegetatif dan kadar gula tanaman tebu (saccharum officinarum l) terhadap suplai nitrogen," Berkala Imliah Pertanian, vol. 1, no. 1, pp. 1-5, 2015.

[13] L. E. Fuentes-Ramírez, J. Caballero-Mellado, J. Sepúlveda, and E. Martínez-Romero, “Colonization of sugarcane by acetobacter diazotrophicus is inhibited by high n-fertilization,"' FEMS Microbiology Ecology, vol. 29, no. 2, pp. 117-128, 1999. doi: 10.1016/s0168-6496(98)00125-1

[14] K. Kwong and B. Pasricha, "The effects of potassium on growth, development, yield and quality of sugarcane," in Proceedings of International Symposium on the Role of Potassium in Nutrient Management for Sustainable Crop Production in India, New Dehli, India, 2002.

[15] F. P. Gardner and R. B. Pearce, Fisiologi Tanaman Budidaya. Jakarta, Indonesia: Universitas Indonesia Press, 1991.

[16] S. Mukhtar, I. Shahid, S. Mehnaz, and K. A. Malik, “Assessment of two carrier materials for phosphate solubilizing biofertilizers and their effect on growth of wheat (triticum aestivum 1.)," Microbiological research, vol. 205, pp. 107--117, 2017. doi: https://doi.org/10.1016/j.micres.2017.08.011

[17] A. D. Khuluq, "Peningkatan produktivitas dan rendemen tebu melalui rekayasa fisiologis pertunasan," Perspektif, vol. 13, no. 1, pp. 13-24, 2015.

[18] S. Hadisaputro, K. Rochiman, P. Mirzawan, G. Sukarso, and B. Sugiharto, “Kajian peran hara nitrogen dan kalium terhadap aktivitas phosphoenolpyruvate carboxylase di dalam daun tebu keprasan varietas m 442-51 dan ps 60," Jurnal Ilmu Dasar, vol. 9, no. 1, pp. 62-71, 2008. 